A detailed reproduction of Admiralty Chart No. 2045 with the dredged areas (in colour) is depicted in this Review. The proposed Midland system $(d)$ is to extend from West London to Stanlow in Cheshire, passing near Northampton, Bromford, Birmingham, with a southern link via St. Albans to Thameshaven, and a Midland branch from Bromford to Nottingham. There are pipe-line grids for the same purpose other than those of the Esso Petroleum Company in contemplation, and awaiting ministerial sanction, but this present account of what has already been accomplished and what is intended from the Fawley base is of great commercial and technical importance, a foretaste of the modern conception of oil distribution to meet the ever-increasing demands for petroleum products.

\section{Fluoridation of Water Supplies}

A воокLET, entitled Fluoridation, prepared by the Ministry of Health for issue to local authorities and other relevant bodies and organizations, is a clear and factual guide to fluoridation (Pp. 8. London: Ministry of Health, 1963). It gives a short account of the results in terms of dental health that are to be obtained by the fluoridation of water supplies, and gives answers in a concise and simple manner to a number of questions that are commonly asked on this topic. It is hoped that this small but lucid pamphlet will have a wide circulation. Though it cannot marshal all the evidence, at least it will show those laymen who have listened to the arguments of the objectors to fluoridation that the recognized dental, medical and public health authorities of Britain, as well as the Government, hold other views.

\section{Livestock Infertility}

A MONOGRAPH has recently been compiled by members of an expert panel of the Food and Agriculture Organization on Livestock Infertility (Animal Health Branch Monograph No. 5. Pp. ii +97. Rome: Food and Agriculture Organization of the United Nations: 1962). The matter is given in eleven chapters, each by an expert on the subject concerned and setting out briefly the salient features of the problems involved. The fields covered include infective agents, heredity, nutrition, management, elimatic conditions, and oducational and research matters concerned with infertility.

\section{Fellowship of the Institute of Biology}

THE Institute of Biology, founded in 1950, has achieved a membership of 3,500 and has recently established a grade of Fellow with the intention of conferring distinction on biologists of high professional standing. The Council of the Institute has invited some 250 members to become the first Fellows and elected the following as honorary Fellows: Lord Adrian, Lord Boyd-Orr, Sir Lindor Brown, Sir Henry Dale, Sir Howard Florey, Sir James Gray, Prof. A. V. Hill, Dr. E. Hindle, Sir Julian Huxley, Sir John Russell and Sir Edward Salisbury.

\section{The Society of Chemical Industry : Plastics and Polymer Group}

THE following have been elected officers and members of the Committee of the Plastics and Polymer Group of the Society of Chemical Industry: Chairman, Dr. G. A. Collie; Vice-Chairman, Dr. J. J. P. Staudinger; Honorary Treasurer, Dr. C. H. Bamford; Honorary Secretary, Mr. K. H. C. Bessant; Honorary Recorder, Dr. M. Gordon; Honorary Hospitality Officer, Mr. R. N. Wheeler; Committee, Prof. C. E. H. Bawn, Mr. R. S. Colbourne, Dr. W. Cooper, Dr. M. H. Dilke, Mr. G. Dring, Dr. W. R. Moore, Dr. W. McG. Morgan, Mr. H. C. Raine, Dr. D. F. Rushman, Dr. L. Valentine, Mr. C. P. Vale, Mr. J. E. S. Whitney.

The annual general meeting of the Group will be held at Shell-Mex House, Strand, London, W.C.2, on June 12. Further information can be obtained from the Assistant
Secretary, Society of Chemical Industry, 14 Belgrave Square, London, S.W.1.

\section{Fellowships in Seismology and Earthquake Engineering}

THE United Nations Special Fund, acting through Unesco, is offering 67 fellowships for study at the International Institute of Seismology and Earthquake Engineering, Tokyo, the main function of which is to give advanced training in seismology and earthquake engineering, particularly to scientists and engineers from those countries lying within the main seismic zones of the world, where the science and applications of seismology are as yet not fully developed. The Government of Japan is also offering fellowships for attendance at the International Institute. The United Kingdom with other Member States has been invited to join the competition that is being organized for the fifteen fellowships available in 1963 under this programme. The period of training commences with a general course including general seismology, seismometry, general geology, engineering seismo$\operatorname{logy}$, soil mechanics, structural dynamics, earthquakeresistant design of buildings, and civil engineering structures, electronic computer techniques. After this follows a special course, either in seismology (theoretical seismology, observational seismology, and seismicity) or in earthquake engineering (soil mechanics and foundation engineering, earthquake-resistant design of buildings and civil engineering structures). The minimum qualification is a university degree or equivalent in mathematics, physics or engineering. Candidates for 1963 fellowships should wite, with full details, to the International Exchange Service, Unesco, Place de Fontenoy, Paris 7 , by June 15.

\section{Announcements}

LORD TODD, professor of organic chemistry in the University of Cambridge, has been elected a trustee of the Ciba Foundation in succession to the late Lord Beveridge.

Dr. KaREL WIESNER, associate director of the Ayerst Research Laboratories, and formerly professor of organic chemistry in the University of New Brunswick, Fredericton, has been awarded the Chemical Institute of Canada Medal for 1963, the highest award of the Institute, which is donated annually by the International Nickel Company of Canada, Ltd.

The annual meeting of holders of Nobel Prizes will be held in Lindau during July 1-5. Further information can be obtained from the Sekretariat der Tagungen der Nobelpreisträger, 899 Lindau $(B)$, Postfach 11.

An international symposium on macromolecular chemistry, arranged by the International Union of Pure and Applied Chemistry, will be held in Paris during July 1-5. Further information can be obtained from the Socretary, International Symposium of Macromolecular Chemistry, 11 rue Pierre-Curie, Paris 5e.

The nineteenth international Congress of Pure and Applied Chemistry, arranged by the International Union of Pure and Applied Chemistry, will be held in London during July 10-17. The Congress will cover inorganic chemistry; organic chemistry; analytical chemistry and applied chemistry. Further information can be obtained from the Honorary Secretary, XIXth IUPAC Congress, 14 Belgrave Square, London, S.W.1.

AN international symposium on "Newcastle Disease Virus as an Evolving Pathogen", arranged by the University of Wisconsin and the American A.ssociation of A.vian Pathologists with the support of the U.S. Department of Agriculture and the National Institutes of Health, will be held in the University of Wisconsin during July 15-17. Further information can be obtained from Prof. R. P. Hanson, Department of Veterinary Science, University of Wisconsin College of Agriculture, Madison 7, Wisconsin. 